University of Nebraska - Lincoln

DigitalCommons@University of Nebraska - Lincoln

$10-10-2018$

\title{
Grain yield, evapotranspiration, and water-use efficiency of maize hybrids differing in drought tolerance
}

\author{
Baozhen Hao \\ Xinxiang University \& Texas A\&M AgriLife Research and Extension Center at Amarillo \\ Qingwu Xue \\ Texas A\&M AgriLife Research and Extension Center at Amarillo, qxue@ag.tamu.edu \\ Thomas H. Marek \\ Texas A\&M AgriLife Research and Extension Center at Amarillo \\ Kirk E. Jessup \\ Texas A\&M AgriLife Research and Extension Center at Amarillo \\ Jacob D. Becker \\ DuPont Pioneer Hybrids
}

See next page for additional authors

Follow this and additional works at: https://digitalcommons.unl.edu/usdaarsfacpub

Hao, Baozhen; Xue, Qingwu; Marek, Thomas H.; Jessup, Kirk E.; Becker, Jacob D.; Hou, Xiaobo; Xu, Wenwei; Bynum, Edsel D.; Bean, Brent W.; Colaizzi, Paul D.; and Howell, Terry A., "Grain yield, evapotranspiration, and water-use efficiency of maize hybrids differing in drought tolerance" (2018). Publications from USDA-ARS / UNL Faculty. 2151.

https://digitalcommons.unl.edu/usdaarsfacpub/2151

This Article is brought to you for free and open access by the U.S. Department of Agriculture: Agricultural Research Service, Lincoln, Nebraska at DigitalCommons@University of Nebraska - Lincoln. It has been accepted for inclusion in Publications from USDA-ARS / UNL Faculty by an authorized administrator of DigitalCommons@University of Nebraska - Lincoln. 


\section{Authors}

Baozhen Hao, Qingwu Xue, Thomas H. Marek, Kirk E. Jessup, Jacob D. Becker, Xiaobo Hou, Wenwei Xu, Edsel D. Bynum, Brent W. Bean, Paul D. Colaizzi, and Terry A. Howell 


\title{
Grain yield, evapotranspiration, and water-use efficiency of maize hybrids differing in drought tolerance
}

\author{
Baozhen Hao ${ }^{1,2}$. Qingwu Xue ${ }^{2} \cdot$ Thomas H. Marek ${ }^{2} \cdot$ Kirk E. Jessup ${ }^{2}$. Jacob D. Becker ${ }^{3}$ Xiaobo Hou ${ }^{4} \cdot$ Wenwei Xu$^{5}$. \\ Edsel D. Bynum ${ }^{2} \cdot$ Brent W. Bean $^{6} \cdot$ Paul D. Colaizzi $^{7}$. Terry A. Howell ${ }^{7}$
}

Received: 23 August 2018 / Accepted: 5 October 2018 / Published online: 10 October 2018

(c) Springer-Verlag GmbH Germany, part of Springer Nature 2018

\begin{abstract}
Adoption of drought-tolerant (DT) hybrids is a viable strategy for maize production in drought-prone environments. We conducted four-year field studies (2011-2014) to investigate yield, crop evapotranspiration (ETc), and water-use efficiency (WUE) in one conventional (N58L) and one DT hybrid (N59B-DT) under three water regimes $\left(\mathrm{I}_{100}, \mathrm{I}_{75}\right.$, and $\mathrm{I}_{50}$, where the subscripts were the percentage of irrigation applied relative to meeting full ETc) and three plant densities. At $\mathrm{I}_{100}$ and $\mathrm{I}_{75}$, N59B-DT did not show advantage in yield and WUE relative to N58L, however, at $\mathrm{I}_{50}$ it showed an advantage of $8.5 \%$ and $10.5 \%$, respectively. At $\mathrm{I}_{100}$ and $\mathrm{I}_{75}$, high plant density treatment had greater grain yield (9.1\%) and WUE (9.4\%) than low plant density. Comparing hybrids, N59B-DT had greater yield (5.9\%) and WUE (7.3\%) than N58L at high plant density. N59B-DT had large advantage over N58L in yield (18.0\%) and WUE $(26.2 \%)$ when the hybrids were grown under severe water deficit $\left(\mathrm{I}_{50}\right)$ and high plant density $\left(9.9\right.$ plants $\left.\mathrm{m}^{-2}\right)$. At $\mathrm{I}_{50}$, increasing plant density reduced yield $(14.1 \%)$ for $\mathrm{N} 58 \mathrm{~L}$ but did not affect yield for N59B-DT. On average, plant density had no effect on seasonal ETc but N59B-DT had more seasonal ETc than N58L at $\mathrm{I}_{100}$ and $\mathrm{I}_{75}$. The results of this study indicate that DT hybrid was tolerant to high panting density. Planting a DT hybrid with a higher plant density may provide greater yield stability under water-limited conditions while also maintaining maximum yield potential when moisture is sufficient.
\end{abstract}

\section{Introduction}

The global population is expected to reach 9.4 billion by 2050 (USCB 2015). It is predicted that the world will need $44 \%$ more cereal production by 2050 , relative to the 2005

Communicated by E. Scudiero.

Qingwu Xue

qxue@ag.tamu.edu

1 School of Science and Technology, Xinxiang University, Xinxiang 453003, Henan, China

2 Texas A\&M AgriLife Research and Extension Center at Amarillo, Amarillo, TX 79106, USA

3 DuPont Pioneer Hybrids, Dalhart, TX 79045, USA

4 Department of Soil, Water and Environmental Science, The University of Arizona, Tucson, AZ 85721, USA

5 Texas A\&M AgriLife Research and Extension Center at Lubbock, Lubbock, TX 79403, USA

6 United Sorghum Checkoff, Lubbock, TX 79403, USA

7 USDA-ARS, Conservation and Production Research Laboratory, Bushland, TX 79012, USA level of production (Fischer et al. 2014). Maize (Zea mays L.) is currently the most important food and feed crop in total global production (Ort and Long 2014). To meet the goal of a $44 \%$ increase in cereal production, global maize production will need to increase from 736 million $\mathrm{Mg}$ in 2005 to 1178 million $\mathrm{Mg}$ (Alexandratos and Bruinsma 2012; Fischer et al. 2014). The United States is by far the world's largest producer and exporter of maize, accounting for $38 \%$ of global maize production and 52\% of global maize exports over the last 10 years (NCGA 2015). Therefore, maize production in the United States is an important determinant of the world maize supply. One of the most important environmental stresses affecting maize production in the United States is drought (Campos et al. 2006; Lobell et al. 2014; Sammons et al. 2014). For example, in 2012, the severe and widespread drought in the United States led to reductions of $21 \%$ and $15 \%$ in national maize yields and maize production, respectively (Boyer et al. 2013; Edmeades 2013). New research has suggested that drought may become more severe in the US Southwest and Great Plains in the coming decades due to climate change (Cook et al. 2015). 
Maize grain yield in the United States increased by about $100 \mathrm{~kg} \mathrm{ha}^{-1}$ year $^{-1}$ or $2 \%$ year $^{-1}$ from 1939 to 2004 , and about $75 \%$ of the yield improvement has been attributed to genetic gain (Tollenaar and Lee 2006; Araus et al. 2008, 2012). The genetic gain was associated with better tolerance to stress such as drought and high plant density (Cassman 1999; Duvick 1999, 2005; Tollenaar et al. 2000; Tollenaar and Lee 2002, 2006; Gonzalez et al. 2018). Drought tolerance is an important component for the success of maize hybrids grown in drought-prone environments (Cooper et al. $2014 a, b)$, and will be of even greater importance in the future as water resources for agronomic uses become even more limiting (Bruce et al. 2002). Seed companies are using diverse strategies such as conventional breeding and genetic engineering to produce new hybrids with enhanced tolerance to drought stress (Claeys and Inzé 2013; McKersie 2015). Monsanto (Monsanto Company, St. Louis, MO, USA) has released its new biotech transgenic DT DroughtGard maize hybrid (MON 87460), which was shown to enhance productivity in water-limited environments, and without yield penalty under favorable moisture conditions (Castiglioni et al. 2008; Chang et al. 2014; Nemali et al. 2014; Sammons et al. 2014). Additionally, Syngenta's Agrisure Artesian and Pioneer's Optimum AQUAmax programs have successfully released a number of non-transgenic DT maize hybrids using conventional breeding (Syngenta-US, http://www.synge nta-us.com; DuPont Pioneer, Johnston, IA, USA). Previous studies have reported that Pioneer's AQUAmax hybrids have a yield advantage under drought conditions with little or no yield penalty under favorable growing conditions as compared with non-AQUAmax hybrids (Pioneer 2013; Cooper et al. 2014a; Gaffney et al. 2015; Hao et al. 2015a). In addition, Mounce et al. (2016) in the High Plains of Texas observed that, compared with the conventional hybrid, the AQUAmax hybrid had lower water use and greater water-use efficiency. However, there have been few studies that have investigated the yield performance and water use of Syngenta's recently released DT Agrisure Artesian maize hybrids.

Tollenaar and Wu (1999) suggested that, under waterlimited conditions, maize productivity under high plant density is generally associated with resistance to drought stress. Cooper et al. (2014a) found that, compared to drought-sensitive hybrids, Pioneer AQUAmax hybrids showed higher tolerance to moderate and higher plant density under waterlimited conditions. Similarly, Gaffney et al. (2015) reported that AQUAmax hybrids maintained an approximate $8 \%$ yield advantage over the non-AQUAmax hybrids under higher population densities and water-limited conditions. It has also been found that the newer maize hybrids have higher optimum plant density than the older hybrids (Duvick 2005). For example, in the US Corn Belt, the yield plateau occurred at about 3 plants $\mathrm{m}^{-2}$ for maize hybrids released up to the 1960 s and about $5-6$ plants $\mathrm{m}^{-2}$ for hybrids released in the 2000s (Hammer et al. 2009). Recently, Hao et al. (2015a) reported that, as plant density increased from 5.9 to 8.4 plants $\mathrm{m}^{-2}$, AQUAmax maize yield increased markedly under well-watered conditions but did not respond to plant density under severe water stress conditions. However, little information is known about the yield response to plant density in recently released Syngenta DT Agrisure Artesian maize hybrids, especially under water-limited environments. Hence, our objectives were (1) to investigate water use, grain yield and water-use efficiency (WUE) of an Agrisure Artesian DT hybrid under different water regimes, and (2) to evaluate the response of the DT hybrid to plant density compared to a conventional hybrid.

\section{Materials and methods}

\section{Experimental site}

The field experiments were conducted at the Texas A\&M AgriLife North Plains Research Field near Etter, TX $\left(35^{\circ} 60^{\prime} \mathrm{N}, 101^{\circ} 59^{\prime} \mathrm{W}\right.$; elevation $1114 \mathrm{~m}$ above mean sea level) from 2011 to 2014. The soil type in the experimental area was a Sherm silty clay loam. The chemical properties of the $0-0.3 \mathrm{~m}$ soil layer were as follows: $\mathrm{pH} 7.6,60 \mathrm{~kg} \mathrm{KCl}-$ extracted $\mathrm{NO}_{3}-\mathrm{N} \mathrm{ha}^{-1}, 13 \mathrm{mg} \mathrm{kg}^{-1}$ of Mehlich-3-extractable $\mathrm{P}, 404 \mathrm{mg} \mathrm{kg}^{-1}$ ammonium acetate-extractable- $\mathrm{K}$ and $11 \mathrm{~g}$ organic matter $\mathrm{kg}^{-1}$. Meteorological data for the 2011, 2012, 2013, and 2014 maize growing seasons were obtained from an agricultural meteorological station located at the experimental site, which was part of the Texas High Plains Evapotranspiration (TXHPET) network (Table 1). Daily data were obtained from the TXHPET website (https://txhighplainset. tamu.edu/weather.jsp).

\section{Experimental design and treatments}

The experimental design was a split-split plot design with four replications. The whole plot factor was irrigation treatment with the combination of hybrid and plant density as sub-plot factor. There were three irrigation treatments $\left(\mathrm{I}_{100}\right.$, $\mathrm{I}_{75}$, and $\mathrm{I}_{50}$, where the subscripts were the percentage of irrigation applied relative to meeting full crop evapotranspiration, ETc) and three plant densities (9.9, 7.9, and 5.9 plants $\mathrm{m}^{-2}$ ). The plant density in this study refers to seeding density in terms of seeds per square meter. All fields were irrigated with a center pivot irrigation system using low elevation spray application (LESA) heads. In each season (except 2014), no irrigation was applied before planting and initial irrigations were applied right after planting in all the plots at a uniform level $\left(\mathrm{I}_{100}\right)$ to ensure uniform emergence and stands. For the $\mathrm{I}_{100}$ treatment, irrigation scheduling was determined according to reference evapotranspiration 
Table 1 Summary of monthly average maximum air temperature $\left(T_{\max }\right)$, minimum air temperature $\left(T_{\min }\right)$, reference evapotranspiration (ETo), and precipitation during the 2011, 2012, 2013, and 2014 growing seasons at Etter, Texas

\begin{tabular}{lllllllll}
\hline Parameter & Year & May & June & July & Aug. & Sept. & Oct. & Mean/total \\
\hline$T_{\max }\left({ }^{\circ} \mathrm{C}\right)$ & 2011 & 26.6 & 35.3 & 37.1 & 35.8 & 28.2 & 23.2 & 31.0 \\
& 2012 & 28.4 & 33.9 & 35.3 & 33.2 & 29.2 & 21.9 & 30.3 \\
& 2013 & 27.5 & 33.6 & 31.9 & 32.6 & 30.0 & 22.6 & 29.7 \\
& 2014 & 27.0 & 30.9 & 31.8 & 33.8 & 26.7 & 22.9 & 28.9 \\
$T_{\min }\left({ }^{\circ} \mathrm{C}\right)$ & 2011 & 7.8 & 16.3 & 18.9 & 18.6 & 11.6 & 5.6 & 13.1 \\
& 2012 & 10.9 & 16.5 & 18.5 & 16.1 & 11.3 & 4.2 & 12.9 \\
& 2013 & 8.8 & 16.6 & 17.4 & 17.3 & 14.2 & 3.8 & 13.0 \\
& 2014 & 8.8 & 15.8 & 17.3 & 16.6 & 13.4 & 6.9 & 13.1 \\
ETo (mm) & 2011 & 234 & 272 & 237 & 202 & 152 & 132 & 1229 \\
& 2012 & 217 & 235 & 241 & 196 & 152 & 119 & 1160 \\
& 2013 & 224 & 250 & 197 & 180 & 152 & 126 & 1129 \\
Precipitation (mm) & 2014 & 204 & 210 & 201 & 199 & 125 & 101 & 1040 \\
& 2011 & 16 & 1 & 13 & 33 & 27 & 13 & 102 \\
& 2012 & 0 & 54 & 6 & 37 & 55 & 8 & 160 \\
& 2013 & 4 & 30 & 58 & 53 & 43 & 7 & 196 \\
& 2014 & 80 & 33 & 50 & 59 & 24 & 4 & 252 \\
\hline
\end{tabular}

(ETo), a crop coefficient, and available soil water at the root zone on a daily basis (Marek et al. 2011). Maize crop coefficients were previously determined using the large lysimeters at the USDA-ARS facility at Bushland Texas. Plant available soil water (PAW) was estimated as the difference between current root zone soil water and that at the lower limit (-1.5 MPa) (Marek et al. 2011). The initial soil water content in the root zone was measured by the gravimetric method using soil cores. Then, the daily soil water balance was calculated using the initial soil water content and subtracting ETc. The irrigation requirement was adjusted based on $90 \%$ application efficiency for LESA system (Kapanigowda et al. 2010). Total plant available water (TAW) was estimated from the soil water at upper $(-0.033 \mathrm{MPa})$ and lower (-1.5 MPa) limits (Marek et al. 2011), and irrigation events were initiated generally when the root zone soil PAW reached to $50 \%$ of TAW. For the $\mathrm{I}_{75}$ and $\mathrm{I}_{50}$ treatments, irrigation frequency was the same as that of the $\mathrm{I}_{100}$ treatment and the irrigation amount was proportional to that of the $\mathrm{I}_{100}$ treatment, using nozzles with a reduced rate once the crop was established (27-31 days after planting) from 2011 to 2013 . However, the reduced irrigation rate started earlier in 2014. The total irrigation amounts for the $\mathrm{I}_{100}, \mathrm{I}_{75}$, and $\mathrm{I}_{50}$ treatments were 754, 584, and $414 \mathrm{~mm}$, respectively, in 2011, 612, 473, and $334 \mathrm{~mm}$, respectively, in 2012, 608, 474 , and $340 \mathrm{~mm}$, respectively, in 2013, and 651, 490, and $326 \mathrm{~mm}$, respectively, in 2014 (Fig. 1).

The hybrids used were N58L (106-day relative maturity) and N59B-DT (107-day relative maturity) from Syngenta Seeds Company. Both hybrids had high yield potential, strong seedling vigor and stalk strength. The two hybrids had similar height but differed in their drought-tolerance characteristics with N59B-DT being designated as the DT hybrid with Agrisure Arteisan trait (Syngenta-US, http:// www.syngenta-us.com). The maize was planted on May 3, 2011, May 10, 2012, May 16, 2013, and May 14, 2014, using a four-row Max-Emerge (John Deere, East Moline, IL) planter. The plots were harvested in mid-October in each season, using a Massie Ferguson 8-XP Plot Combine (Kincaid Equipment Manufacturing, Haven, Kansas, USA).

Each plot was $3.0 \mathrm{~m}$ wide and $9.1 \mathrm{~m}$ long and consisted of four rows spaced at $0.76 \mathrm{~m}$. The cropping system was a corn-wheat rotation with strip tillage. The field was fertilized before planting at 334-111-0-0 (N-P-K-S) $\mathrm{kg} \mathrm{ha}^{-1}$ in 2011, 278-112-0-33 (N-P-K-S) $\mathrm{kg} \mathrm{ha}^{-1}$ in 2012 and 290-109-0-11 (N-P-K-S) $\mathrm{kg} \mathrm{ha}^{-1}$ in 2014, based on soil testing. In 2013, 100-67-0-0 (N-P-K-S) $\mathrm{kg} \mathrm{ha}^{-1}$ was applied before planting, and $100 \mathrm{~kg} \mathrm{ha}^{-1} \mathrm{~N}$ was applied by fertigation during the growing season. Weed control involved herbicide applications at pre-plant and post-emergence. One aerial application of Oberon (spiromesifen) was conducted for spider mite (Tetranychus urticae) control in 2011 and 2013.

\section{Measurements}

In the 2011, 2012, and 2013 seasons, gravimetric soil water contents were determined by taking soil cores at $0-0.15,0.15-0.3,0.3-0.6,0.6-0.9$, and $0.9-1.2 \mathrm{~m}$ depth at planting and after harvest. Six soil cores were collected in the field of each irrigation level at planting, and one soil core was taken in each subplot after harvest. Gravimetric soil water in each depth was converted to volumetric water by multiplying by the soil bulk density, which was measured by taking soil cores. Crop seasonal ETc was 

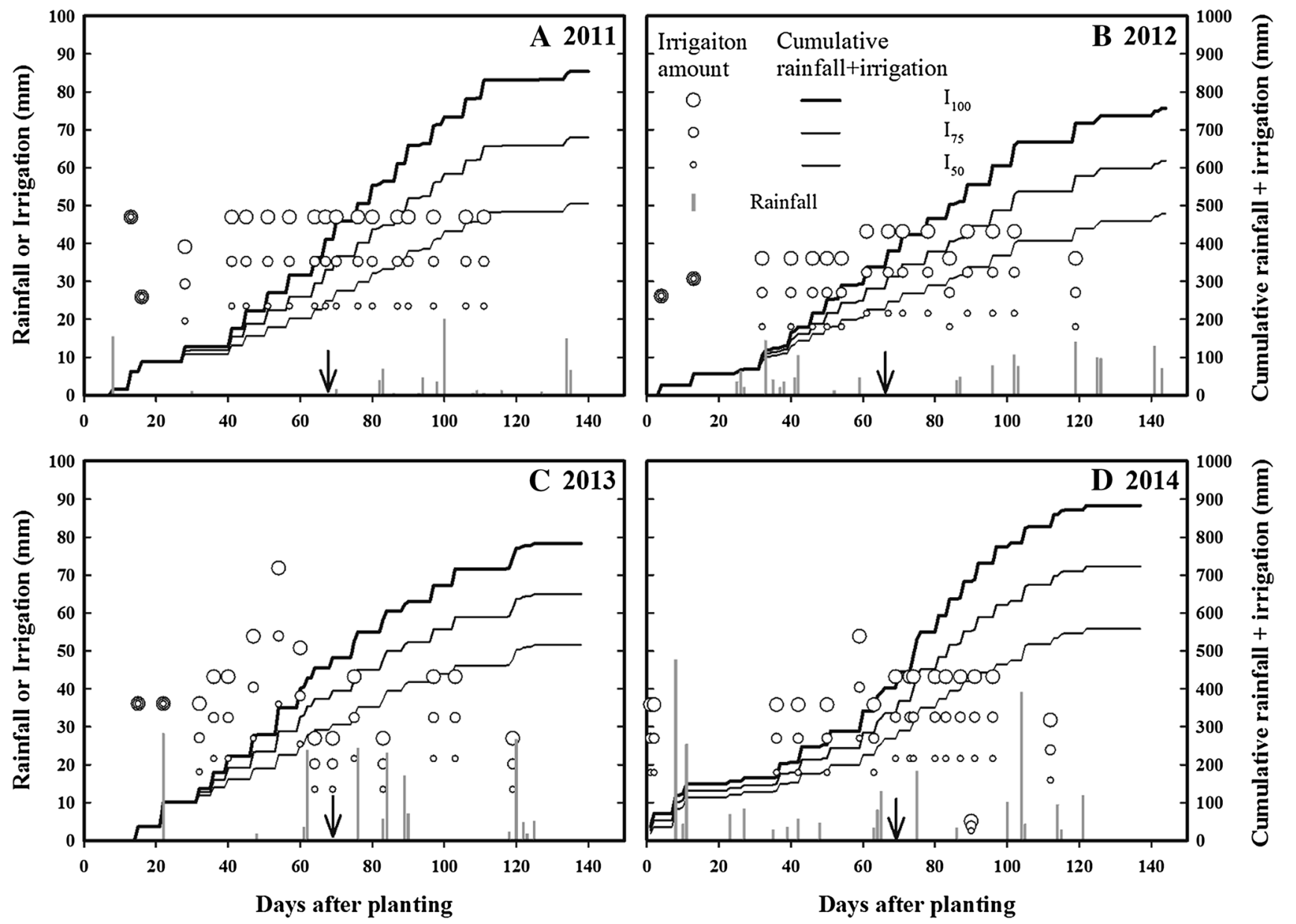

Fig. 1 Rainfall and irrigation, and cumulative rainfall and irrigation during the 2011 (a), 2012 (b), 2013 (c), and 2014 (d) maize growing seasons at Etter, Texas. Arrows indicate the silking dates

determined by summing the precipitation, applied irrigation water, and the difference of soil water in the $0-1.2 \mathrm{~m}$ profile between planting and post-harvest. We assumed runoff and deep percolation were negligible. The field was furrow diked and plots were leveled, and the irrigation system speed was manually adjusted to uniformly apply water to the soil at a rate less than the soil intake rate to prevent runoff from occurring. In another maize study at the same field with the same center pivot irrigation system, we measured soil water content at $1.4 \mathrm{~m}$ throughout the growing season in 2012 and 2013, which indicated no movement of water into lower soil depths (Hao et al. 2015b). In 2014 season, the soil water contents were only measured in the plots with medium plant density (7.9 seeds $\left.\mathrm{m}^{-2}\right)$. Therefore, the ETc data were not included in this season. Water-use efficiency (WUE, $\mathrm{kg} \mathrm{m}^{-3}$ ) was calculated as the ratio of grain yield and seasonal ETc. Yield was determined by harvesting the central two rows in each plot and grain moisture was adjusted to $15.5 \%$.

\section{Statistical analysis}

Statistical analysis was conducted using the SAS v9.2 statistical program (SAS Institute Inc. 2009). Analysis of variance (ANOVA) was conducted by the PROC MIXED procedure to evaluate each factor and interaction. The year, water regime, hybrid, and plant density were treated as fixed effects. Replication was considered a random effect. Mean values were compared by least significant difference (LSD) at the $5 \%$ level.

\section{Results}

\section{Weather conditions}

Weather conditions in this study varied markedly among the four growing seasons (Table 1). The 2011 season was unusually dry and hot and represented the second driest season of record. The 2013 and 2014 seasons were relatively 
cool and wet. The average maximum air temperatures for June, July, and August in 2011 were higher than in 2012 and much higher than in 2013 and 2014. The seasonal rainfall (May-October) was lower in 2011 and 2012 than in 2013 and 2014. In the 2011 growing season, only three rainfall events of more than $10 \mathrm{~mm}$ occurred. In 2012, approximately $40 \%$ of seasonal rainfall occurred during the later growth period (September and October). Seasonal rainfall

Table 2 Analysis of variance $(P>F)$ of maize grain yield (GY), seasonal crop evapotranspiration (ETc), and water-use efficiency (WUE) as affected by water regime (WR), hybrid (HB), and plant density (PD)

\begin{tabular}{lrrrrr}
\hline Effect & $d f$ & \multicolumn{1}{l}{ GY } & $d f$ & \multicolumn{1}{l}{ ETc } & \multicolumn{1}{l}{ WUE } \\
\hline Year (Y) & 3 & $<0.0001$ & 2 & $<0.0001$ & $<0.0001$ \\
Water regime (WR) & 2 & $<0.0001$ & 2 & $<0.0001$ & 0.0001 \\
Hybrid (HB) & 1 & 0.0003 & 1 & 0.0016 & 0.2623 \\
Plant density (PD) & 2 & $<0.0001$ & 2 & 0.6973 & 0.0003 \\
Y $\times$ WR & 6 & $<0.0001$ & 4 & $<0.0001$ & $<0.0001$ \\
Y $\times$ HB & 3 & 0.2977 & 2 & 0.0849 & 0.1325 \\
Y $\times$ PD & 6 & $<0.0001$ & 4 & 0.0005 & $<0.0001$ \\
WR $\times$ HB & 2 & 0.1641 & 2 & 0.0516 & 0.0041 \\
WR $\times$ PD & 4 & $<0.0001$ & 4 & 0.9676 & 0.0075 \\
HB $\times$ PD & 2 & 0.0460 & 2 & 0.1241 & 0.0069 \\
Y $\times$ WR $\times$ HB & 6 & 0.0955 & 4 & 0.2242 & 0.0008 \\
Y $\times$ WR $\times$ PD & 12 & 0.2399 & 8 & 0.1370 & 0.2155 \\
Y $\times$ HB $\times$ PD & 6 & 0.4795 & 4 & 0.5024 & 0.7126 \\
WR $\times$ HB $\times$ PD & 4 & 0.4505 & 4 & 0.5236 & 0.2411 \\
Y $\times$ WR $\times$ HB $\times$ PD & 12 & 0.2233 & 8 & 0.1968 & 0.8598 \\
\hline
\end{tabular}

in 2011, 2012, 2013, and 2014 only accounted for $8 \%, 14 \%$, $17 \%$, and $24 \%$ of seasonal ETo (May-October), respectively.

\section{Grain yield}

Grain yield was affected significantly $(P<0.05)$ by all main effects and all two-way interactions except year $\times$ hybrid $(P=0.2977)$ and water regime $\times$ hybrid $(P=0.1641)$ (Table 2 ). The three-way year $\times$ water regime $\times$ hybrid interaction for grain yield was significant at $P<0.10$ level (Table 2). In each season, grain yield decreased with decreasing irrigation supply (Table 3 ). Compared to $\mathrm{I}_{100}$, grain yield at $\mathrm{I}_{75}$ decreased more in $2011(12.4 \%)$ and 2012 (14.7\%) than in $2013(4.0 \%)$ and $2014(0.7 \%)$. These differences may be caused by the adverse climatic conditions in 2011 and 2012 compared to 2013 and 2014. At $\mathrm{I}_{50}$, grain yield decreased more and ranged from 29.8 to $48.7 \%$ compared to $\mathrm{I}_{100}$.

The grain yield of the two hybrids showed different responses to water regime among the 4 years (Table 3). At $\mathrm{I}_{100}$ and $\mathrm{I}_{75}$, the yield difference between the two hybrids was generally small and not significant, except at $\mathrm{I}_{75}$ in 2014, in which, N59B-DT had greater yield than N58L. At $\mathrm{I}_{50}$, N59B-DT generally had greater grain yield than N58L. Averaged across year and plant density, grain yield of N58L was reduced by $8.2 \%^{-1}$ at $\mathrm{I}_{75}$ and $42.9 \%$ at $\mathrm{I}_{50}$ as compared to $\mathrm{I}_{100}$ (Table 3). The corresponding values for N59B-DT were only $6.9 \%$ and $38.9 \%$ at $\mathrm{I}_{75}$ and $\mathrm{I}_{50}$, respectively. The results indicate that N59B-DT had less yield reduction under water stress as compared to N58L.
Table 3 Grain yield (GY), seasonal crop evapotranspiration (ETc), and water-use efficiency (WUE) of the two hybrids under three water regimes during the 2011, 2012, 2013, and 2014 maize growing seasons at Etter, Texas

\begin{tabular}{|c|c|c|c|c|c|c|c|c|c|c|}
\hline \multirow[t]{2}{*}{ Year } & \multirow[t]{2}{*}{ Hybrid } & \multicolumn{3}{|c|}{ GY $\left(\mathrm{Mg} \mathrm{ha}^{-1}\right)$} & \multicolumn{3}{|c|}{$\mathrm{ETc}(\mathrm{mm})$} & \multicolumn{3}{|c|}{ WUE $\left(\mathrm{kg} \mathrm{m}^{-3}\right)$} \\
\hline & & $\mathrm{I}_{100}$ & $\mathrm{I}_{75}$ & $\mathrm{I}_{50}$ & $\mathrm{I}_{100}$ & $\mathrm{I}_{75}$ & $\mathrm{I}_{50}$ & $\mathrm{I}_{100}$ & $\mathrm{I}_{75}$ & $\mathrm{I}_{50}$ \\
\hline \multirow[t]{3}{*}{2011} & N58L & $12.18 \mathrm{a}^{\dagger}$ & $10.53 \mathrm{a}$ & $6.05 \mathrm{~b}$ & $749 \mathrm{a}$ & $572 \mathrm{a}$ & $488 \mathrm{a}$ & $1.63 \mathrm{a}$ & $1.84 \mathrm{a}$ & $1.24 \mathrm{~b}$ \\
\hline & N59B-DT & $12.54 \mathrm{a}$ & $11.14 \mathrm{a}$ & $6.63 a$ & $758 \mathrm{a}$ & $578 \mathrm{a}$ & $489 a$ & $1.65 \mathrm{a}$ & $1.93 \mathrm{a}$ & $1.36 \mathrm{a}$ \\
\hline & Mean & $12.36 \mathrm{~A}^{\ddagger}$ & $10.83 \mathrm{~B}$ & $6.34 \mathrm{C}$ & $753 \mathrm{~A}$ & $575 B$ & $489 \mathrm{C}$ & $1.64 \mathrm{~B}$ & $1.89 \mathrm{~A}$ & $1.30 \mathrm{C}$ \\
\hline \multirow[t]{3}{*}{2012} & N58L & $11.93 \mathrm{a}$ & $10.01 \mathrm{a}$ & $6.51 \mathrm{a}$ & $623 a$ & $562 \mathrm{a}$ & $485 \mathrm{a}$ & $1.91 \mathrm{a}$ & $1.82 \mathrm{a}$ & $1.35 \mathrm{a}$ \\
\hline & N59B-DT & $12.02 \mathrm{a}$ & $10.42 \mathrm{a}$ & $6.73 a$ & $629 a$ & $568 \mathrm{a}$ & $487 \mathrm{a}$ & $1.93 \mathrm{a}$ & $1.86 a$ & $1.36 \mathrm{a}$ \\
\hline & Mean & $11.98 \mathrm{~A}$ & $10.21 \mathrm{~B}$ & $6.62 \mathrm{C}$ & $626 \mathrm{~A}$ & $565 \mathrm{~B}$ & $486 \mathrm{C}$ & $1.92 \mathrm{~A}$ & $1.84 \mathrm{~A}$ & $1.36 \mathrm{~B}$ \\
\hline \multirow[t]{3}{*}{2013} & N58L & $12.58 \mathrm{a}$ & $12.20 \mathrm{a}$ & $8.17 \mathrm{~b}$ & $616 b$ & $530 \mathrm{~b}$ & $482 \mathrm{a}$ & $2.04 \mathrm{a}$ & $2.30 \mathrm{a}$ & $1.68 \mathrm{~b}$ \\
\hline & N59B-DT & $12.32 \mathrm{a}$ & $11.69 \mathrm{a}$ & $9.27 \mathrm{a}$ & $645 a$ & $560 \mathrm{a}$ & $476 a$ & $1.92 \mathrm{~b}$ & $2.08 \mathrm{~b}$ & $1.95 \mathrm{a}$ \\
\hline & Mean & $12.45 \mathrm{~A}$ & $11.96 \mathrm{~A}$ & $8.47 \mathrm{~B}$ & $631 \mathrm{~A}$ & $545 B$ & $479 \mathrm{C}$ & $1.98 \mathrm{~B}$ & $2.20 \mathrm{~A}$ & $1.82 \mathrm{C}$ \\
\hline \multirow[t]{3}{*}{2014} & N58L & $14.36 \mathrm{a}$ & $14.12 b$ & $8.47 \mathrm{a}$ & $-\S$ & - & - & - & - & - \\
\hline & N59B-DT & $14.80 \mathrm{a}$ & $14.86 \mathrm{a}$ & $8.97 \mathrm{a}$ & - & - & - & - & - & - \\
\hline & Mean & $14.58 \mathrm{~A}$ & $14.49 \mathrm{~A}$ & $8.72 \mathrm{~B}$ & - & - & - & - & - & - \\
\hline
\end{tabular}

${ }^{\dagger}$ Within each year in each column for each water regime, means with the same lowercase letter were not significantly different at $P=0.05$

$¥$ Within each year in each row, means with the same uppercase letter were not significantly different at $P=0.05$

${ }^{\S}$ Seasonal crop evapotranspiration and water-use efficiency were not measured in 2014 
The effect of plant density on grain yield (across hybrids) was different under the three water regimes (Table 4). At $\mathrm{I}_{100}$ and $\mathrm{I}_{75}$, higher plant density resulted in greater grain yield. At $\mathrm{I}_{50}$, grain yield did not increase significantly when plant density increased from 5.9 to 7.9 plants $\mathrm{m}^{-2}$, and decreased significantly as plant density increased to 9.9 plants $\mathrm{m}^{-2}$. These results indicated that increased plant density would result in increased yield under well-watered conditions, and caused some yield reduction under water-limited conditions. Both hybrids at all three water regimes showed an increase in grain yield when plant density increased from 5.9 to 7.9 plants $\mathrm{m}^{-2}$, and the average increase was a little higher for $\mathrm{N} 58 \mathrm{~L}$ than N59B-DT. However, as plant density increased from 7.9 to 9.9 plants $\mathrm{m}^{-2}$, at both $\mathrm{I}_{100}$ and $\mathrm{I}_{75}$, grain yield did not change for $\mathrm{N} 58 \mathrm{~L}$, whereas a slight yield increase was observed for N59B-DT, and at $\mathrm{I}_{50}$, grain yield did not change for N59B-DT but was reduced by $14.1 \%$ for N58L. A significant difference in grain yield between hybrids was only detected at $\mathrm{I}_{50}$ with high plant density, at which grain yield was $18.0 \%$ greater for N59B-DT than N58L. These results indicated that, under sufficient water supply $\left(\mathrm{I}_{100}\right)$ or mild water stress $\left(\mathrm{I}_{75}\right)$, N59B-DT always responded positively to increased plant density (5.9-7.9-9.9 plants $\mathrm{m}^{-2}$ ), but N58L only responded positively to increased plant density of 5.9-7.9 plants $\mathrm{m}^{-2}$. Under severe water stress $\left(\mathrm{I}_{50}\right)$, N59B-DT did not respond negatively to increased plant density, but N58L did show a negative response. Across hybrids, on average, grain yield for the high plant density was $11.8 \%$ and $6.4 \%$ greater than for the low plant density at $I_{100}$ and $I_{75}$, respectively (Table 4).

\section{Evapotranspiration}

The seasonal ETc was affected significantly $(P<0.05)$ by year, water regime and hybrid, but not by plant density $(P=0.6973)$. In addition, the water regime $\times$ hybrid interaction was significant at $P<0.10$ level (Table 2). On average, the seasonal ETc for $\mathrm{I}_{100}, \mathrm{I}_{75}$, and $\mathrm{I}_{50}$ water regimes was 673 , 561 , and $484 \mathrm{~mm}$, respectively (Table 3), suggesting a 16.6\% and $28.1 \%$ reduction in seasonal ETc when irrigation was reduced from $\mathrm{I}_{100}$ to $\mathrm{I}_{75}$ and $\mathrm{I}_{50}$, respectively. Hybrid differences in seasonal ETc were related to water regime. At $\mathrm{I}_{50}$, the two hybrids had similar seasonal ETc. However, N59BDT had greater seasonal ETc than N58L at both $\mathrm{I}_{100}$ and $\mathrm{I}_{75}$. Compared to the 2011 season, the 2012 and 2013 seasons had lower seasonal ETc, which was due to the hot and dry conditions in 2011 that resulted in high ETo (Table 3).

\section{Water-use efficiency}

At both $\mathrm{I}_{100}$ and $\mathrm{I}_{75}$, N59B-DT generally had similar or lower WUE than N58L for 3 years (Table 3). At $\mathrm{I}_{50}$, WUE was significantly higher for N59B-DT than that for N58L in 2011 and 2013. However, no significant differences in WUE were observed between N59B-DT and N58L in 2012. Averaged across hybrids, the $\mathrm{I}_{50}$ treatment consistently had the lowest WUE in all 3 years. The $\mathrm{I}_{75}$ treatment had greater WUE in 2011 and 2013, and slightly less WUE in 2012 as compared to $\mathrm{I}_{100}$ (Table 3). Compared to $\mathrm{I}_{100}$, WUE increased by $7.4 \%$ at $\mathrm{I}_{75}$ but decreased by $22.7 \%$ at $\mathrm{I}_{50}$ (Table 3 ). At $\mathrm{I}_{100}$ and $\mathrm{I}_{75}$, there were no significant differences in WUE (across hybrids) between the high and moderate plant density, and both had significantly higher WUE than the low
Table 4 Maize grain yield and water-use efficiency (WUE) for the two hybrids under three plant densities and three water regimes at Etter, Texas

\begin{tabular}{|c|c|c|c|c|c|c|c|}
\hline \multirow[t]{3}{*}{ Water regime } & \multirow[t]{3}{*}{ Hybrid } & \multicolumn{6}{|c|}{ Plant density (plants $\mathrm{m}^{-2}$ ) } \\
\hline & & \multicolumn{3}{|c|}{ Grain yield $\left(\mathrm{Mg} \mathrm{ha}^{-1}\right)$} & \multicolumn{3}{|c|}{ WUE $\left(\mathrm{kg} \mathrm{m}^{-3}\right)$} \\
\hline & & 5.9 & 7.9 & 9.9 & 5.9 & 7.9 & 9.9 \\
\hline \multirow[t]{3}{*}{$\mathrm{I}_{100}$} & N58L & $11.80 \mathrm{a}^{\dagger} \mathrm{B}^{\ddagger}$ & $13.25 \mathrm{aA}$ & $13.24 \mathrm{aA}$ & $1.71 \mathrm{aB}$ & $1.93 \mathrm{aA}$ & $1.91 \mathrm{aA}$ \\
\hline & N59B-DT & $12.18 \mathrm{aB}$ & $13.02 \mathrm{aA}$ & $13.57 \mathrm{aA}$ & $1.73 \mathrm{aB}$ & $1.82 \mathrm{aAB}$ & $1.94 \mathrm{aA}$ \\
\hline & Mean & 11.99B & $13.13 \mathrm{~A}$ & $13.40 \mathrm{~A}$ & $1.72 \mathrm{~B}$ & $1.88 \mathrm{~A}$ & $1.93 \mathrm{~A}$ \\
\hline \multirow[t]{3}{*}{$\mathrm{I}_{75}$} & N58L & $11.22 \mathrm{aB}$ & $11.95 \mathrm{aA}$ & $11.97 \mathrm{aA}$ & $1.92 \mathrm{aA}$ & $2.06 \mathrm{aA}$ & $2.04 \mathrm{aA}$ \\
\hline & N59B-DT & $11.60 \mathrm{aB}$ & $12.20 \mathrm{aA}$ & $12.31 \mathrm{aA}$ & $1.85 \mathrm{aB}$ & $1.97 \mathrm{aAB}$ & $2.06 \mathrm{aA}$ \\
\hline & Mean & 11.41B & $12.07 \mathrm{~A}$ & $12.14 \mathrm{~A}$ & $1.89 \mathrm{~B}$ & $2.02 \mathrm{~A}$ & $2.05 \mathrm{~A}$ \\
\hline \multirow[t]{3}{*}{$\mathrm{I}_{50}$} & N58L & $7.35 \mathrm{aAB}$ & 7.80aA & $6.70 \mathrm{bB}$ & $1.46 \mathrm{aA}$ & $1.52 \mathrm{aA}$ & $1.29 \mathrm{bB}$ \\
\hline & N59B-DT & $7.85 \mathrm{aA}$ & $7.94 \mathrm{aA}$ & $7.90 \mathrm{aA}$ & $1.52 \mathrm{aA}$ & $1.57 \mathrm{aA}$ & $1.63 \mathrm{aA}$ \\
\hline & Mean & 7.60AB & $7.87 \mathrm{~A}$ & $7.30 \mathrm{~B}$ & $1.49 \mathrm{~A}$ & $1.54 \mathrm{~A}$ & $1.46 \mathrm{~A}$ \\
\hline \multirow[t]{2}{*}{ Mean } & N58L & $10.18 \mathrm{aC}$ & $11.00 \mathrm{aA}$ & $10.64 \mathrm{bB}$ & $1.70 \mathrm{aB}$ & $1.84 \mathrm{aA}$ & $1.75 \mathrm{bB}$ \\
\hline & N59B-DT & $10.54 \mathrm{aB}$ & $11.03 \mathrm{aA}$ & $11.26 \mathrm{aA}$ & $1.70 \mathrm{aB}$ & $1.78 \mathrm{aB}$ & $1.88 \mathrm{aA}$ \\
\hline
\end{tabular}

${ }^{\dagger}$ Within each water regime in each column for each plant density, means with the same lowercase letter were not significantly different at $P=0.05$

${ }^{\ddagger}$ Within each water regime in each row, means with the same uppercase letter were not significantly different at $P=0.05$ 
plant density (Table 4). On average, WUE at $\mathrm{I}_{100}$ and $\mathrm{I}_{75}$ was greater at the high plant density than at the low plant density, respectively. There were no significant differences in WUE (across water regimes) between N59B-DT and N58L at the low and moderate plant density. But WUE was significantly greater for N59B-DT than N58L at the high plant density.

\section{Discussion}

\section{Grain yield}

Providing grain yield stability under water-limited conditions is a major goal of breeding drought-tolerant hybrids in maize (Campos et al. 2004, 2006). In our results, the DT hybrid N59B-DT had greater yield than the conventional N58L in 2 of 4 years $\left(2011,9.6 \%\right.$ or $0.58 \mathrm{Mg} \mathrm{ha}^{-1} ; 2013$, $13.5 \%$ or $1.10 \mathrm{Mg} \mathrm{ha}^{-1}$ ) under severe water stress conditions $\left(\mathrm{I}_{50}\right)$. In our results, under severe water stress conditions $\left(\mathrm{I}_{50}\right)$, the DT hybrid N59B-DT did not show yield advantage relative to $\mathrm{N} 58 \mathrm{~L}$ under low and moderate densities, but under high density $\left(9.9\right.$ plants $\left.\mathrm{m}^{-2}\right)$, it had greater yield than $\mathrm{N} 58 \mathrm{~L}$. At $\mathrm{I}_{50}$, N58L produced more grain at moderate density compared to low and high densities; however, the yield of N59B-DT did not differ among three densities. Previous reports had shown that Pioneer AQUAmax hybrids also had yield benefits when compared to non-AQUAmax hybrids under water-limited conditions (Cooper et al. 2014a; Gaffney et al. 2015; Zhao et al. 2018). Recently, under water-limited conditions, Gaffney et al. (2015) reported that grain yield (across 2006 locations) was $0.37 \mathrm{Mg} \mathrm{ha}^{-1}$ (6.5\%) greater in AQUAmax hybrids than in non-AQUAmax hybrids, and Hao et al. (2015a) pointed out that two AQUAmax hybrids yielded $1.19 \mathrm{Mg} \mathrm{ha}^{-1}$ (19.1\%) more than the conventional hybrid. In addition, Sammons et al. (2014) reported that the Monsanto MON 87460 can provide a yield advantage relative to a control hybrid under water-limited conditions, and Nemali et al. (2014) reported that grain yields (across the years 2007-2010) were $0.7 \mathrm{Mg} \mathrm{ha}^{-1}$ (8.8\%) greater in MON 87460 than in a control hybrid. However, due to the complexities of drought (e.g., drought timing, duration, intensity, and interactions with soil type), DT hybrids may not always show a yield benefit (Gaffney et al. 2015). For example, in Northwest Indiana, Roth et al. (2013) reported that no yield advantage was observed in AQUAmax hybrids when compared to non-AQUAmax hybrids.

Besides drought-tolerance, as farmers adopt droughttolerant hybrids, they are also concerned about the yield potential of DT hybrids when water supply is sufficient (Boyer et al. 2013). Therefore, yield performance under both drought and favorable environmental conditions needs to be considered in breeding for drought tolerance in maize (Ziyomo and Bernardo 2013). In this study, N59B-DT at the $\mathrm{I}_{100}$ treatment yielded $12.92 \mathrm{Mg} \mathrm{ha}^{-1}$ compared to $12.76 \mathrm{Mg} \mathrm{ha}^{-1}$ for $\mathrm{N} 58 \mathrm{~L}$, indicating there was no yield penalty for the DT hybrid under well-watered conditions. Similar results are reported by Nemali et al. (2014) and Sammons et al. (2014), using MON 87460, and Gaffney et al. (2015) and Hao et al. (2015a), using AQUAmax hybrids. However, Cooper et al. (2014a) found that, when compared with drought-sensitive hybrids under the conditions of sufficient water supply, there was a small yield penalty for the AQUAmax hybrid.

\section{Evapotranspiration}

In this study, N59B-DT showed greater seasonal ETc at both $\mathrm{I}_{100}$ and $\mathrm{I}_{75}$, and the same seasonal ETc at $\mathrm{I}_{50}$ as compared to N58L. These results are different from a more recent study conducted at the same location, in which Pioneer DT hybrids had the same or less seasonal ETc relative to a conventional hybrid for all irrigation regimes $\left(\mathrm{I}_{100}, \mathrm{I}_{75}\right.$, and $\mathrm{I}_{50}$ ) (Hao et al. 2015a). Contrasting results between studies could be related to different water use characteristic between Agrisure Artesian and AQUAmax hybrids. In this study, seasonal ETc at $\mathrm{I}_{100}$ ranged from 608 to $774 \mathrm{~mm}$, which was within the range (571-984 mm) measured during 1975-1994 in the Texas High Plains (Steiner et al. 1991; Howell et al. 1995, 1998). Additionally, other studies on the Texas High Plains showed similar ETc values. For example, a synthesis of the 15-year period from 1991 to 2006 showed that crop evapotranspiration for maize was $745 \mathrm{~mm}$ (Kapanigowda et al. 2010). In addition, for maize under favorable moisture conditions, Colaizzi et al. (2011) reported seasonal ETc of 711-815 mm. Our results also showed that the average seasonal ETc at $\mathrm{I}_{75}$ and $\mathrm{I}_{50}$ was $561 \mathrm{~mm}$ and $484 \mathrm{~mm}$, respectively. At the same water regime, Colaizzi et al. (2011) reported seasonal ETc of $696 \mathrm{~mm}\left(\mathrm{I}_{75}\right)$ and $574 \mathrm{~mm}\left(\mathrm{I}_{50}\right)$ in their 2010 field study. The different findings could be explained by the relatively low grain yield in this study (11.87 and $7.59 \mathrm{Mg} \mathrm{ha}^{-1}$ for $\mathrm{I}_{75}$ and $\mathrm{I}_{50}$, respectively) compared to Colaizzi et al. (2011) (14.07 and $11.84 \mathrm{Mg} \mathrm{ha}^{-1}$, respectively).

\section{Water-use efficiency}

Our results showed that higher WUE in N59B-DT $\left(1.57 \mathrm{~kg} \mathrm{~m}^{-3}\right)$ than $\mathrm{N} 58 \mathrm{~L}\left(1.42 \mathrm{~kg} \mathrm{~m}^{-3}\right)$ at $\mathrm{I}_{50}$ was associated with greater grain yield (8.5\%) and almost the same seasonal ETc $(-0.2 \%)$ in N59B-DT relative to N58L. Similar to these results, Hao et al. (2015a) recently reported that DT hybrids consistently had higher WUE than a check hybrid at $\mathrm{I}_{50}$, resulting from greater grain yield and less or similar seasonal ETc. However, the data from the current study indicated that no differences in WUE were detected between N59B-DT and N58L at $\mathrm{I}_{75}$, which was different from the results of Hao et al. (2015a). 
In this study, WUE for $\mathrm{I}_{100}$ and $\mathrm{I}_{75}$ water regimes was relatively lower in $2011\left(1.43-2.15 \mathrm{~kg} \mathrm{~m}^{-3}\right)$ than in 2012 and $2013\left(1.70-2.33 \mathrm{~kg} \mathrm{~m}^{-3}\right)$, which was associated with higher evaporative demand and higher temperature in 2011. Based on prior studies conducted in the Texas High Plains from 1975 to 1994 , the estimated WUE range for maize was $1.15-1.99 \mathrm{~kg} \mathrm{~m}^{-3}$, measured under the conditions from fully irrigated to mildly water limited (Steiner et al. 1991; Howell et al. 1995, 1998). These results suggested that newer maize hybrids used in this study tend to have higher WUE than those hybrids used in the other studies due to the increased yield but similar or reduced ET in this study (Steiner et al. 1991; Howell et al. 1995, 1998). In this study, the highest WUE was obtained at $\mathrm{I}_{75}$, which was $7.4 \%$ greater than that at $\mathrm{I}_{100}$, and the lowest WUE was obtained at $\mathrm{I}_{50}$, which was $22.7 \%$ lower than that at $\mathrm{I}_{100}$. Contrary to our findings, higher WUE values at $\mathrm{I}_{50}$ than $\mathrm{I}_{75}$ and $\mathrm{I}_{100}$ were reported by Aydinsakir et al. (2013) and Colaizzi et al. (2011), in which, ETc and yield at $\mathrm{I}_{50}$ was reduced by $29.4-32.0 \%$ (28.1\% in this study) and $15.6-18.6 \%$ (40.9\% in this study), respectively, compared to that at $\mathrm{I}_{100}$. These differences may be attributed to more favorable climatic conditions in Colaizzi et al. (2011) (milder temperatures) and Aydinsakir et al. (2013) (lower evaporative demand) compared with this study.

\section{Plant density}

Increased plant density has been a major change in maize management practice in the United States since the 1930s (Duvick 2005). Water supply needs to be taken into consideration before increasing plant density in maize production (Lyon et al. 2003). Our results showed that higher plant density resulted in greater grain yield as well as higher WUE under sufficient water supply $\left(\mathrm{I}_{100}\right)$ or mild water stress $\left(\mathrm{I}_{75}\right)$. Under severe water stress $\left(\mathrm{I}_{50}\right)$, grain yield and water-use efficiency did not respond to plant density as plant density increased from 5.9 to 7.9 plants $\mathrm{m}^{-2}$, and grain yield showed a significant decrease as plant density increased from 7.9 to 9.9 plants $\mathrm{m}^{-2}$, particularly for the conventional hybrid N58L. Hao et al. (2015a) reported similar results.

Enhanced response to high plant density as well as drought stress in modern hybrids has made a large contribution to the yield improvement of maize over the past 30 years (Cassman 1999; Duvick 1999, 2005; Tollenaar et al. 2000; Tollenaar and Lee 2002, 2006). Our results indicated that, under non- and mild water stress, the yield of DT hybrid showed increasing trend with increasing density, while the yield did not change for conventional hybrid as density increased from 7.9 to 9.9 plants $\mathrm{m}^{-2}$; under severe water stress $\left(\mathrm{I}_{50}\right)$, N59B-DT did not respond negatively to increased plant density, but N58L did show a negative response. The responses of yield for DT hybrid to increased density in this study are similar to the results reported by Cooper et al. (2014a). However, Roth et al. (2013) and Hao et al. (2015a) found that, in both non-limiting and water-limiting environments, the yield of DT hybrids did not increase with increasing plant density as compared to conventional hybrids. Contrasting results among the studies were presumably due to differences in hybrids, plant densities, and drought conditions. In this study, grain yield at $\mathrm{I}_{100}$ and $\mathrm{I}_{75}$ was increased by $11.8 \%$ and $6.4 \%$, respectively, as plant density increased from 5.9 to 9.9 plants $\mathrm{m}^{-2}$. Correspondingly, Hao et al. (2015a) reported a yield increase of $6.3 \%\left(\mathrm{I}_{100}\right)$ and $5.8 \%\left(\mathrm{I}_{75}\right)$ when plant density increased from 5.9 to 8.4 plants $\mathrm{m}^{-2}$.

\section{Conclusion}

In most cases, DT hybrid produced more grain as compared with conventional hybrid under sufficient water supply and mild water stress. As planting density increased from 7.9 to 9.9 plants $\mathrm{m}^{-2}$, the yield of DT hybrid showed increasing trend with increasing density, while the yield did not change for conventional hybrid. In the severely water-limited environment $\left(\mathrm{I}_{50}\right)$, the yield advantage of DT hybrid only occurred at high plant density (9.9 plants $\left.\mathrm{m}^{-2}\right)$, the DT hybrid N59B-DT showed yield (18.0\%) and WUE (26.2\%) advantages over the conventional hybrid N58L. Therefore, planting a DT hybrid with a higher plant density may provide greater yield stability under water-limited conditions while also maintaining maximum yield potential when moisture is sufficient.

Acknowledgements We are grateful to Texas A\&M AgriLife Research staff of Chance Reynolds, Brad Parker, Cole Pope, Bella Porras, Bronc Finch, and Preston Sirmon for their help in field and laboratory work. This research was supported in part by Texas A\&M AgriLife Research Cropping System Program, Syngenta-US Seeds, Inc., the USDA-Ogallala Aquifer Program, Key Science and Technology Program of Henan (172102110154), and the USDA National Institute of Food and Agriculture Hatch Project, USA (TEX09438).

\section{References}

Alexandratos N, Bruinsma J (2012) World agriculture towards 2030/2050: the 2012 revision. ESA working paper no. 12-03. Food and Agriculture Organization of the United Nations (FAO), Rome

Araus JL, Slafer GA, Royo C, Serret MD (2008) Breeding for yield potential and stress adaptation in cereals. Crit Rev Plant Sci 27:377-412

Araus JL, Serret MD, Edmeades GO (2012) Phenotyping maize for adaptation to drought. Front Physiol 3:1-20

Aydinsakir K, Erdal S, Buyuktas D, Bastug R, Toker R (2013) The influence of regular deficit irrigation applications on water use, yield, and quality components of two corn (Zea mays L.) genotypes. Agric Water Manag 128:65-71 
Boyer JS, Byrne P, Cassman KG, Cooper M, Delmer D, Greene T, Gruis F, Habben J, Hausmann N, Kenny N, Lafitte R, Paszkiewicz S, Porter D, Schlegel A, Schussler J, Setter T, Shanahan J, Sharp RE, Vyn TJ, Warner D, Gaffney J (2013) The U.S. drought of 2012 in perspective: a call to action. Glob Food Security 2:139-143

Bruce W, Edmeades GO, Barker TC (2002) Molecular and physiological approaches to maize improvement for drought tolerance. J Exp Bot 53:13-25

Campos H, Cooper M, Habben JE, Edmeades GO, Schussler JR (2004) Improving drought tolerance in maize: a view from industry. Field Crops Res 90:19-34

Campos H, Cooper M, Edmeades GO, Löffler C, Schussler JR, Ibañez $M$ (2006) Changes in drought tolerance in maize associated with fifty years of breeding for yield in the US Corn Belt. Maydica $51: 369-381$

Cassman KG (1999) Ecological intensification of cereal production systems: Yield potential, soil quality, and precision agriculture. Proc Natl Acad Sci 96:5952-5959

Castiglioni P, Warner D, Bensen RJ, Anstrom DC, Harrison J, Stoecker M, Abad M, Kumar G, Salvador S, D'Ordine R, Navarro S, Back S, Fernandes M, Targolli J, Dasgupta S, Bonin C, Luethy MH, Heard JE (2008) Bacterial RNA chaperones confer abiotic stress tolerance in plants and improved grain yield in maize under waterlimited conditions. Plant Physiol 147:446-455

Chang J, Clay DE, Hansen SA, Clay SA, Schumacher TE (2014) Water stress impacts on transgenic drought-tolerant corn in the Northern Great Plains. Agron J 106:125-130

Claeys H, Inzé D (2013) The agony of choice: How plants balance growth and survival under water-limiting conditions. Plant Physiol 162:1768-1779

Colaizzi PD, Evett SR, Howell TA (2011) Corn production with spray, LEPA, and SDI. In: Proceedings of the 23rd annual central plains irrigation conference, Burlington, CO. 22-23 Feb 2011. Central Plains Irrig. Assoc., Colby, KS, pp 52-67

Cook BI, Ault TR, Smerdon JE (2015) Unprecedented 21st century drought risk in the American Southwest and Central Plains. Sci Adv 1:e1400082

Cooper M, Gho C, Leafgren R, Tang T, Messina C (2014a) Breeding drought-tolerant maize hybrids for the US corn-belt: discovery to product. J Exp Bot 65:6191-6204

Cooper M, Messina CD, Podlich D, Totir LR, Baumgarten A, Hausmann NJ, Wright D, Graham G (2014b) Predicting the future of plant breeding: complementing empirical evaluation with genetic prediction. Crop Pasture Sci 65:311-336

Duvick DN (1999) Heterosis: feeding people and protecting natural resources. In: Coors JG, Pandey S editors, the genetics and exploitation of heterosis in crops. ASA, CSSA, and SSSA, Madison, pp 19-29

Duvick DN (2005) The contribution of breeding to yield advances in maize (Zea mays L.). Adv Agron 86:83-145

Edmeades GO (2013) Progress in achieving and delivering drought tolerance in maize - an update. ISAAA, Ithaca

Fischer RA, Byerlee D, Edmeades GO (2014) Crop yields and global food security: will yield increase continue to feed the world? ACIAR Monogr. 158. Australian Centre for Int. Agric. Res., Canberra

Gaffney J, Schussler J, Löffler C, Cai W, Paszkiewicz S, Messina C, Groeteke J, Keaschall J, Cooper M (2015) Industry-scale evaluation of maize hybrids selected for increased yield in drought-stress conditions of the US Corn Belt. Crop Sci 55:1608-1618

Gonzalez VH, Tollenaar M, Bowman A, Good B, Lee EA (2018) Maize yield potential and density tolerance. Crop Sci 58:1-14

Hammer GL, Dong Z, McLean G, Doherty A, Messina C, Schussler J, Zinselmeier C, Paszkiewicz S, Cooper M (2009) Can changes in canopy and/or root system architecture explain historical maize yield trends in the US Corn Belt? Crop Sci 49:299-312
Hao B, Xue Q, Marek TH, Jessup KE, Becker J, Hou X, Xu W, Bynum ED, Bean BW, Colaizzi PD, Howell TA (2015a) Water use and grain yield in drought-tolerant corn in the Texas High Plains. Agron J 107:1922-1930

Hao B, Xue Q, Marek TH, Jessup KE, Hou X, Xu W, Bynum ED, Bean BW (2015b) Soil water extraction, water use, and grain yield by drought-tolerant maize on the Texas High Plains. Agric Water Manag 155:11-21

Howell TA, Yazar A, Schneider AD, Dusek DA, Copeland KS (1995) Yield and water-use efficiency of corn in response to LEPA irrigation. Trans ASAE 38:1737-1747

Howell TA, Tolk JA, Schneider AD, Evett SR (1998) Evapotranspiration, yield, and water-use efficiency of corn hybrids differing in maturity. Agron J 90:3-9

Kapanigowda M, Stewart BA, Howell TA, Kadasrivenkata H, Baumhardt RL (2010) Growing maize in clumps as a strategy for marginal climatic conditions. Field Crops Res 118:115-125

Lobell DB, Roberts MJ, Schlenker W, Braun N, Little BB, Rejesus RM, Hammer GL (2014) Greater sensitivity to drought accompanies maize yield increase in the US Midwest. Science 344:516-519

Lyon DJ, Hammer GL, McLean GB, Blumenthal JM (2003) Simulation supplements field studies to determine no-till dryland corn population recommendations for semiarid Western Nebraska. Agron J 95:884-891

Marek TH, Porter DP, Kenny NP, Gowda PH, Howell TA, Moorhead JE (2011) Educational enhancements to the texas high plains evapotranspiration (ET) network. AREC Publ 2011-8. Technical report for the Texas Water Development Board, Austin, Texas. Texas A\&M AgriLife Res., Amarillo

McKersie B (2015) Planning for food security in a changing climate. J Exp Bot 66:3435-3450

Mounce RB, O'Shaughnessy SA, Blaser BC, Colaizzi PD (2016) Crop response of drought-tolerant and conventional maize hybrids in a semiarid environment. Irrig Sci 34:231-244

NCGA (2015) National Corn Growers Association-National Corn Yield Content (2011-2014). http://www.ncga.com/for-farmers/ national-corn-yield-contest. Accessed 27 Jan 2015

Nemali KS, Bonin C, Dohleman FG, Stephens M, Reeves WR, Nelson DE, Castiglioni P, Whitsel JE, Sammons B, Silady RA, Anstrom D, Sharp RE, Patharkar OR, Clay D, Coffin M, Nemeth MA, Leibman ME, Luethy M, Lawson M (2014) Physiological responses related to increased grain yield under drought in the first biotechnology-derived drought-tolerant maize. Plant Cell Environ 38:1866-1880

Ort DR, Long SP (2014) Limits on yields in the Corn Belt. Science 344:484-485

Pioneer (2013) Optimum ${ }^{\circledR}$ AQUAmax ${ }^{\mathrm{TM}}$ products from DuPont Pioneer. DuPont Pioneer. http://www.pioneer.com/CMRoot/Pioneer/ US/products/seed_trait_technology/see_the_difference/AQUAm ax_Product_Offerings.pdf. Accessed 31 Dec 2014

Roth JA, Ciampitti IA, Vyn TJ (2013) Physiological evaluations of recent drought-tolerant maize hybrids at varying stress levels. Agron J 105:1129-1141

Sammons B, Whitsel J, Stork LG, Reeves W, Horak M (2014) Characterization of drought-tolerant maize MON 87460 for use in environmental risk assessment. Crop Sci 54:719-729

SAS Institute Inc (2009) SAS/STAT 9.2 user's guide. SAS Institute, Inc., Cary

Steiner JL, Howell TA, Tolk JA, Schneider AD (1991) Evapotranspiration and growth predictions of CERES maize, sorghum and wheat in the Southern High Plains. In: Proceeding of the 1991 ASCE irrigation and drainage conference, Honolulu, HI. 22-26 July 1991. ASCE, New York, pp 297-303

Tollenaar M, Lee EA (2002) Yield potential, yield stability and stress tolerance in maize. Field Crops Res 75:161-169 
Tollenaar M, Lee EA (2006) Dissection of physiological processes underlying grain yield in maize by examining genetic improvement and heterosis. Maydica 51:399-408

Tollenaar M, Wu J (1999) Yield improvement in temperate maize is attributable to greater stress tolerance. Crop Sci 39:1597-1604

Tollenaar M, Ying J, Duvick DN (2000) Genetic gain in corn hybrids from the Northern and Central Corn Belt. In: Proceedings of the 55th corn and sorghum research conference, Chicago, IL. 5-8 Dec 2000. ASTA, Washington, D.C., pp 53-62

USCB (2015) World population 1950-2050. International database. http://www.census.gov/population/international/data/worldpop/ table_population.php. Accessed 31 Mar 2015
Zhao J, Xue Q, Jessup KE, Hao B, Hou X, Marek TH, Xu W, Evett SR, O'Shaughnessy SA, Brauer DK (2018) Yield and water use of drought-tolerant maize hybrids in a semiarid environment. Field Crops Res 216:1-9

Ziyomo C, Bernardo R (2013) Drought tolerance in maize: indirect selection through secondary traits versus genomewide selection. Crop Sci 53:1269-1275 